\title{
SUBSTANTIVE CONDITIONS OF ADOPTION REGARDING THE ADOPTING PERSON OR FAMILY
}

\author{
Cristian-Sorin STĂNCIULESCU \\ stanciulescu_cristian87@yahoo.com \\ Paul-Augustin PUŞCAŞ \\ paulpuscas_cj@yahoo.com \\ “LUCIAN BLAGA” UNIVERSITY, SIBIU, ROMANIA
}

\begin{abstract}
This article analyzes the substantive conditions imposed by the Romanian legislator on persons wishing to adopt, the legal circumstances considered to be essential and indispensable for a person or a family to be able to adopt. From a historical point of view, the adoption has been permanently subject to conditions, imposed by the interests of the child without parental protection, of the state or of a logic common sense. The existence of conditions regarding the situation, attributes or aptitudes of the adopter does not contradict the general principle of non-discrimination, recognized and guaranteed by both national and international law. The regulation of restrictions on the possibility of adoption does not amount to discrimination against any citizen, as long as such restrictions or conditions are motivated by interests of a higher order than private ones and apply to all persons in a certain situation. Adoption is a complex social phenomenon due to the emotional implications on those involved in this process.
\end{abstract}

\section{KEYWORDS:}

Legal, civil code, legislation, adoption, procedure

\section{Introduction}

In accordance with Law no. 273/2004 the adopter is defined as "the person who has adopted or wishes to adopt", and the adoptive family consists of "the husband and wife who have adopted or wish to adopt, under the conditions of this law".

From the research of the provisions of the Civil Code and of the provisions of Law no. 273/2004 on the legal regime of adoption, the adopter must meet the following substantive conditions:
- "the adopter has full exercise capacity", art. 459, Civil Code;

- "the adopter is at least 18 years older than the adoptee", art. 460, Civil code;

- "the adopter or the adoptive family fulfils the moral guarantees and material conditions necessary for the full and harmonious development of the child's personality", art. 461, Civil Code;

- "the adoptee is not adopted by several adopters, simultaneously or successively", art. 462, Civil code; 
- "the adopter has not been definitively convicted of an offense against the person or of the family and of the offense of child pornography and trafficking in drugs or precursors", art. 7, Law no 273/2004.

As these are substantive conditions for the very validity of the adoption, they must be met by both, the potential adopter and one who already has that status. In other words, the substantive conditions required by law for adoption regarding the person of the adopter must be met by the adopter both before the moment of adoption and afterwards throughout its duration. Some conditions, such as the age difference between the adoptee and the adopter, cannot change after adoption, but other conditions, such as the capacity to exercise, the existence of moral guarantees and material conditions, or the conviction suffered after the adoption, may be subject to change. These aspects were taken into account by the legislator, the Civil Code regulating in this sense, the cessation of adoption (art. 475-482 Civil Code).

The literature has expressed the view that the adopter must meet the same substantive conditions as a guardian. In line with the work of Bodoașcă (2020) this follows a logic a fortiori, since the adoptive parent is more for the child than a guardian. No doubt this statement is true. In our opinion, it is not necessary to explicitly mention the conditions that must be met by the guardian among the substantive conditions imposed on the adopter, as we would witness a doubling of the regulations. A special situation is represented by the recognition in a family, by the husband, of a child out of wedlock and the wife wants to adopt this child. In this particular case, the adoption follows a simplified procedure, which lacks the steps prior to the approval of the adoption. This simplification of the adoption procedure in such special conditions is beneficial, as the child enters a family in which he already has a natural or adoptive parent, and going through the usual preliminary steps would have been an excessive formality, which could delay useless the moment of adoption itself.

\section{Substantive conditions of adoption regarding the adopting person or family in the domestic law}

\subsection{Full legal capacity condition}

The first substantive condition regarding the adoptive person or family that we will deal with in more detail refers to the existence of the full legal capacity of the adopter. This condition is based on two reasons, namely:

- in order to express the consent valid for adoption, the person of the adopter must have full legal capacity, exactly as it is defined in art. 38, 39 and 40 of the Civil Code, usually at 18 years old and by exception at 16 years old. From the point of view of international law, as it is analysed by Emese (2015) in his studies, the Strasbourg Convention establishes the condition that the adopter has reached the minimum age provided by law for this purpose, which cannot be less than 18 years or more than 30 years, but also provides the possibility of derogations from the minimum age so that the provisions of domestic law are in line with international ones.

- in order for the purpose of the adoption to be achieved, the person wishing to become an adoptive parent must have full legal capacity. Adoption means, according to the doctrine, the protection of the child without the full legal capacity, who needs parental protection, and this protection cannot be achieved by the one who needs protection himself.

In order to simplify the understanding of the first substantive condition imposed on the adoptive person or family, we can conclude that only the persons with full legal capacity can adopt and the following persons can not adopt:

- the person lacking full legal capacity;

- the person who has been definitively convicted of an offense against 
the person or against the family, committed with intent, as well as for the offense of child pornography and offenses relating to trafficking in drugs or precursors;

- the person or family whose child benefits from a special protection measure or who is deprived of parental rights;

- the person who wishes to adopt alone, whose husband is mentally ill, mentally handicapped or has been definitively convicted of an offense against the person or against the family, committed intentionally, for the offense of child pornography, drug or precursor trafficking or forfeiture from parental rights.

\subsection{Existence of a minimum age difference between the adopter and the adopted}

The second substantive condition imposed on the adoptive person or family concerns the existence of an age difference of at least 18 years between the adopter and the adopted. In the Civil Code at art. 460 paragraph (1) stipulates that the adopter must be 18 years older than the adoptee. For good reasons, the guardianship court may approve the adoption even if the age difference is less than 18 years, but not less than 16 years. This aspect is provided in art. 460 paragraph (2) of the Civil Code and it can be observed that the validity of the reasons invoked for the age derogation is left to the discretion of the guardianship court. The reasons are assessed on a caseby-case basis, and the adoption will only be approved if it respects the best interests of the child. As regards the maximum age, the legislator does not set such a limit, nor does the Strasbourg Convention require this, stipulating in Article 9 that " $a$ child may be adopted only if the adopter has reached the minimum age provided for by law for this purpose, this minimum age may not be less than 18 years, nor more than 30 years" and that "there must be an appropriate age difference between the adopter and the child, respecting the best interests of the child, preferably a difference of at least
16 years". The doctrine considers, as we can see in studies made by Ureche, Moloman (2017) that, "an old age would not lead to the fulfilment of the purpose of the adoption, namely its conclusion in the best interests of the child".

\subsection{Moral guarantees and the material conditions}

The third substantive condition imposed on the adoptive person or family refers to the fulfilment of the moral guarantees and the material conditions by them for achieving the purpose of the adoption ensuring the best interests of the child. This condition is provided in Article 461 paragraph (1) of the Civil Code. The evaluation carried out by the General Directorate of Social Assistance and Child Protection in whose territorial area the adopter or adoptive family resides, as it is described by Ureche, Moloman (2017) in their work, aims to analyze the material and moral conditions of the adopter as well as the identification of parental abilities and preparation for him to assume the role of parent.

The way of accomplishment, the time and the finality of the evaluation are described in art. 18 of Law no. 273/2004 on the adoption procedure and follow especially "the personality and state of health of the adopter or adoptive family, family life, living conditions, the ability to raise and educate a child, the economic situation of the person / family, the reasons why the adopter or the adoptive family wishes to adopt, the reasons why, if one of the two spouses requests to adopt a child, the other spouse does not join the application, impediments of any nature relevant to the ability to adopt"

\subsection{The absence of simultaneous or successive adoption condition \\ The fourth substantive condition concerns the absence of simultaneous or successive adoption. This condition provided both in the Civil Code in art. 462}


and in Law 273/2004 in art. 6, paragraph (1), strengthens the principle of raising and educating the child in a family setting and especially, leads to the avoidance of multiple filiation relations. According to art. 6, paragraph (1) of Law 273/2004 "two persons may not adopt together, neither simultaneously nor successively". From this rule, the legislator establishes four exceptions, which refer to the approval of a new adoption if:

- the adopters are husband and wife. The reason for this condition lies in the fact that numerically, a person cannot have more than two parents and thus it is intended that the adoptee has a single mother and a single father. If the applicant for the adoption has become the husband of the adoptive parent after the approval of the adoption, it is natural for such adoption to be approved if it is limited to respecting the best interests of the child;

- death of the adopter or adoptive spouses;

- the previous adoption has ceased;

- "the adopted child has only one parent, unmarried, and he is in a stable relationship and coexists with a person of the opposite sex, unmarried, who is not related to him up to the fourth degree and declares by notarial deed that the new adopter participated directly and directly in the upbringing and care of the child for an uninterrupted period of at least 5 years", as art. 7, law no $273 / 2004$.

\subsection{Non-existence of convictions for certain offenses condition}

The last substantive condition necessary for the adoptive person or family to be able to go through the adoption procedure and achieve its purpose by the court's approval refers to the non-existence of convictions for certain offenses. This negative condition imposed on the adopter is regulated by law 273/2004 art. 7 paragraph (1) and refers to "the person who was definitively convicted for a crime against the person or against the family, committed with intent, as well as for the crime of child pornography and offenses relating to trafficking in drugs or precursors may not be adopted".

3. Substantive conditions of adoption regarding the adopting person or family in Great Britain, France and Germany: a comparative analysis

For a complete analysis of the substantive conditions related to the adoptive person or family, we have chosen to include in this article also elements of comparative law, analyzing the conditions imposed for adoption in three other states, namely England, France and Germany.

In England, the adoption and child law allows the approval of adoption at the request of a person or a couple. This law also defines the couple as consisting of a husband and wife or two people in a cohabitation relationship. In England, two people of the same sex can be adopted together. The age limit imposed on the adopter is 21 years. Adoption by one spouse is also allowed with the justification of the reasons why the other spouse does not join the adoption, and the reasons allowed by law are those that refer to health problems, the disappearance or even separation of the two spouses, if it is one with a permanent character.

The Law on Adoption and the Child also establishes specific requirements regarding the domicile or living conditions of the adopter or the adoptive family. One of these relates to the fact that the adoptive person or family must have had their habitual residence or residence in the last 12 months prior to the application for approval in the United Kingdom.

Adoption cannot be approved if the adopter or one of the persons living with him and over the age of 18 has been criminally convicted.

In France, even if the adoption has two forms, namely full-adoption and limited-adoption, the conditions to be met by the adopter are regulated identically regardless of the form of adoption. 
The French Civil Code stipulates that it may adopt one or two persons together provided that they have been married for at least two years and are not separated.

As regards the age of the adoptive person or family, French law imposes a limit of 28 years. The exception to this rule for the adopter arises when he wants to adopt his husband's child.

Another substantive condition we encounter in French law is the imposition of a 15-year difference between the adoptee and the adopter or the adoptive family. The derogation from this condition is left to the discretion of the court approving the adoption. In French law we also encounter "post mortem adoption". This refers to situations that may arise after the death of the adopter. If the death occurs after the child has been placed for adoption, the application for approval of the adoption may be made on behalf of the deceased adopter by the surviving spouse or one of his or her heirs but the adoptee will not be entitled to the inheritance will benefit from the right to inheritance.

In Germany, the civil code allows adoption by a single person or by two married people. There are also exceptions to this condition, which refer to the married person who can adopt his or her biological or adopted child alone. In the German Civil Code, the minimum age imposed on the adopter is 25 years. There are also two exceptions to this rule that refer to the adoptive family in which one of the spouses has reached the age of 25 , the other being obliged to be at least 21 years old, and the second exception concerns the adoption of the natural child, or adopted of the husband, the minimum age being also 21 years.

The German Civil Code allows the adoption of a child after the death of the adopter, provided that the application for approval has been submitted to the court prior to the death.

\section{Conclusion}

One of the oldest social institutions, adoption still raises, nowadays, questions on whether it serves the best interests of children, who should be allowed to adopt and the role that public institutions of one state has in this process. In what concerns our domestic law and the conditions analysed above we can conclude that substantive conditions regarding the adopter or the adoptive family are in accordance with the international conventions to which Romania is a party and the fact that part of them have changed or modified over the years is a true challenge for the legislator to create favourable premises for fulfilling the purpose of adoption, namely respecting the best interests of the child.

\section{REFERENCES}

Avram, M. (2013). Civil law. Family. Bucharest: Hamangiu Publishing House.

Bodoașcă, T. (2015). Family Law. University course. Bucharest: Universul Juridic Publishing House.

Bodoașcă, T. (2020). Family Law, (4 ${ }^{\text {th }}$ Edition). Cluj-Napoca: Riso Print Publishing House.

Council of European (1968). European Convention on the Adoption of Children. Nr. 058. Available at: https:/www.coe.int/en/web/conventions/full-list//conventions/treaty/058, accessed on 31 July 2021.

Florian, E. (2011). Family Law. (4 ${ }^{\text {th }}$ Edition). Bucharest: CH Beck Publishing House.

Florian, E. (2015). Family law. The marriage. Matrimonial regimes. Affiliation, ( $5^{\text {th }}$ Edition). Bucharest: CH Beck Publishing House.

Parliament of Romania. (2004). Law no. 273 of June 21, 2004 (republished) regarding the adoption procedure. Official Gazette of Romania, Nr. 739. 
Parliament of Romania. (2011). Civil Code. Official Gazette of Romania, Part I, Nr. 505 of July 15, 2011.

Parliament of Romania. (2011). Law no. 138 of July 05, 2011, for the ratification of the revised European Covention on the Adoption of Children, adopted in Strasbourg on 27 November 2008 and signed by Romania in Strasbourg on 04 March 2009. Official Gazette of Romania, Partea I, Nr. 515.

Parliament of Romania. (2013). Law no. 257/2013 for amending and supplementing the Law no. 272/2004 for protection and promotion of children's rights. Official Gazette of Romania, Part I, Nr. 607 of September, $30^{\text {th }} 2013$, by giving the texts a new numbering.

Parliament of Romania. (2016). Law no. 57 of April 11, 2016 for the amendment and completion of Law no. 273/2004 regarding the adoption procedure, as well as other normative acts. Official Gazette of Romania, Nr. 283.

The adoption process in Romania. (n.d.). Available at: http://andpdca.gov.ro/w/adoptie/, accessed on 31 July 2021.

Toncean Luieran, I.R. (2017). Adoption according to the new internal regulations of Romania. Bucharest: Universul Juridic Publishing House.

Ureche, L.C., \& Moloman, B.D. (2017). Guide on the adoption procedure. Bucharest: Universul Juridic Publishing House. 